\title{
電解放電加エにおける印加電圧と電流波形との関係
}

\section{Relationship between applied voltage and current waveform in electrochemical discharge machining}

\author{
Katsushi FURUTANI ${ }^{*}$ \\ ${ }^{* 1}$ Toyota Technological Institute \\ 2-12-1 Hisakata, Tempaku-ku, Nagoya-shi, Aichi 468-8511, Japan
}

Received: 29 May 2020; Revised: 11 August 2020; Accepted: 17 September 2020

\begin{abstract}
Electrochemical discharge machining (ECDM) is a machining method for inorganic insulators. When a tool electrode is fed at a constant rate, the removal rate is often decreased due to enlarging the gap length between the tool electrode and workpiece. In this paper, the effects of the applied voltage, which is a changeable condition during ECDM, and the initial gap length between the tool electrode and workpiece on the current waveforms and machining performance were experimentally investigated. Soda lime glass was machined with a tungsten electrode in $\mathrm{NaCl}$ solution. Plenty amount of bubbles were generated below an applied voltage of $45 \mathrm{~V}$, and the removal amount was large. Though discharge strongly occurred over 50 $\mathrm{V}$, the removal amount was small. With an increase of the applied voltage, lower frequency components of the current measured during ECDM were decreased. The initial gap did not affect the current waveforms. The mixture of long and short pulses accelerated removal at a low applied voltage. The phenomena around the tool electrode such as the bubble generation and discharge were distinguished by the principal component analysis (PCA). After a series of current pulses was divided into 12 periods, their statistical parameters were calculated, and the frequency components were calculated by the first Fourier transform. In both the cases, the applied voltage was distinguished by the PCA. The principal components obtained from the statistical parameter performed as essential parameters.
\end{abstract}

Keywords : Electrochemical discharge machining, ECDM, Applied voltage, Current, Initial gap, Machined area, Glass, Principal component analysis

\section{1. 緒言}

ガラス，圧電セラミックスなどの無機絶縁体への微細加工法の一つとして，電解放電加工が研究されている (Arya and Dvivedi, 2019; Elhami and Razfar, 2020). ガラス $\left(\mathrm{SiO}_{2}\right)$ の電解放電加工では，ナトリウムイオン（Na $\left.{ }^{+}\right)$ を含む電解液中に設置した工具電極を陰極として，ガラスに $0.01 \mathrm{~N}$ オーダの力で押し付けた状態で電圧を印加す る. 約 $40 \mathrm{~V}$ 以上では電気分解により水素の泡が発生するとともにその中で放電が発生する.この熱により $\mathrm{SiO}_{2}$ と $\mathrm{Na}$ との化学反応が促進され，水溶性の $\mathrm{Na}_{2} \mathrm{SiO}_{3}$ が生成される．これが加工液中に溶出することで除去が進む(土 屋他，1987). 泡の界面もしくは泡の中で放電が発生するため(Basak and Ghosh, 1996), 加工量や形状は泡の発生量 や流れの方向の影響を受ける(Liao et al., 2013; Furutani et al., 2014).

著者らは，これまでに軸対称形状に加工する旋盤型電解放電加工機を製作し，クラックが少ない加工が可能で あることを示した(Furutani and Maeda, 2008). 形状を加工する際には工具電極を半径方向と軸長手方向に送る必要 がある．旋盤型加工機では，工具ホルダの軸長手方向および主分力方向の剛性が低いと，工具電極先端の位置決 め誤差が大きくなる。したがって，細軸の高精度加工のためには高剛性なホルダを用いた定速送りで行った (Furutani and Kojima, 2016). しかし，工具電極を工作物に衝突させないように低速で送ると，それらの間隔が開く

No.20-00197 [DOI:10.1299/transjsme.20-00197], J-STAGE Advance Publication date : 30 September, 2020

本論文は，第13回生産加工・工作機械部門講演会 講演論文集(2019), No. B20の掲載内容に基づいた論文である.

*1 正員, 豊田工業大学（广468-8511 愛知県名古屋市天白区久方 2-12-1）

E-mail of corresponding author: furutani@toyota-ti.ac.jp 
場合があった１ 1 本の電極で定速送り加工を行った場合だけでなく，一体にした多電極を用いて加工する場合に (Arab et al., 2019）電極ごとに加工量にばらつきがあると, 電極と加工物間の距離がばらつき, 加工特性が一定に ならないと考えられる.

一方, 多数の加工条件を最適化したり, さまざまなデータから加工状態を推定する際に次元を減少させる方法 として, 統計的手法である主成分分析などを用いることがある(Ancio et al., 2016; 辻野他, 2017). 電気加工分野に おいても，放電加工における放電状態の判別に分散分析を適用したり (Abidi et al., 2017), 電解加工の加工条件最 適化のために主成分分析や分散分析を適用した例がある(Kasdekar and Parashar, 2018). さらに進んで，機械学習に よりワイヤ放電加工の加工条件を最適化した例もある(Huang et al., 2018). 電解放電加工では, 印加電圧およびパ ルス状に与えるときにはそのデューティー比, 加工液濃度などを変えて加工特性を測定することが多い(Kim et al., 2006; Cao et al., 2009). 加工状態の観察として，放電加工と同様にパルス幅と電流值により 分類したパルスの頻度 を測定した例がある(Furutani et al., 2018).

本論文では，印加電圧および工具電極と工作物との間隙が電流波形および加工特性に与える影響を穴加工につ いて実験的に調べた結果について述べる，電流の解析に主成分分析を用いることで，電流波形が加工特性に影響 を与える因子を明らかにする.

\section{2. 実験装置と方法}

実験装置の構成を図 1 に示寸．陰極である工具電極と陽極である補助電極が電解液の中に浸されている．アー ム先端に取り付けられている工具電極の位置を調整するためには手動 XYZ ステージを用いた. XY 方向は最小目 盛 $10 \mu \mathrm{m}$ のマイクロメータで, $\mathrm{Z}$ 方向は最小目盛 $0.5 \mu \mathrm{m}$ の差動マイクロメータで変位させた. ステージ変位はこ れらのマイクロメータで読み取った. 工具電極の Z 方向変位は, 差動マイクロメータのバックラッシの影響を受 けないように，電気マイクロメータで測定した。

実験条件を表 1 に示寸. 工具電極は直径 $0.3 \mathrm{~mm}$ のタングステン棒で, 突き出し量を $10 \sim 12 \mathrm{~mm}$ としてピンバイ スで保持した. 補助電極は電気分解の影響を受けにくいように，グラファイトを用いた．工作物を厚さ約 $1.5 \mathrm{~mm}$ のソーダ石灰ガラスとして, $60 \mathrm{~s}$ 間加工した. 電解液は $20 \mathrm{wt} \%$ の $\mathrm{NaCl}$ 水溶液とした. 加工液は工作物表面上 $4 \mathrm{~mm}$ まで満たした，加工中には加工液梁さは変化しなかった．印加電圧は放電が発生する最低電圧である $40 \mathrm{~V}$ から $55 \mathrm{~V}$ までの間で, $5 \mathrm{~V}$ きざみで変化させた。電極初期位置は, 完全に接触した状態 $0 \mu \mathrm{m}$ と， $25 ， 50 \mu \mathrm{m}$ 間隔をあけ た位置とし，加工中は固定した。これらの条件ごとに 5 回ずつ加工した.

初期間隙の調整は以下の手順で行った。

（1）Z 軸ステージの差動マイクロメータの粗動で $50 \mu \mathrm{m}$ ずつ電極を下げる（極間を縮める）。接触するまでは, 差動マイクロメータによる駆動量と電気マイクロメータで読み取った変位が一致している.

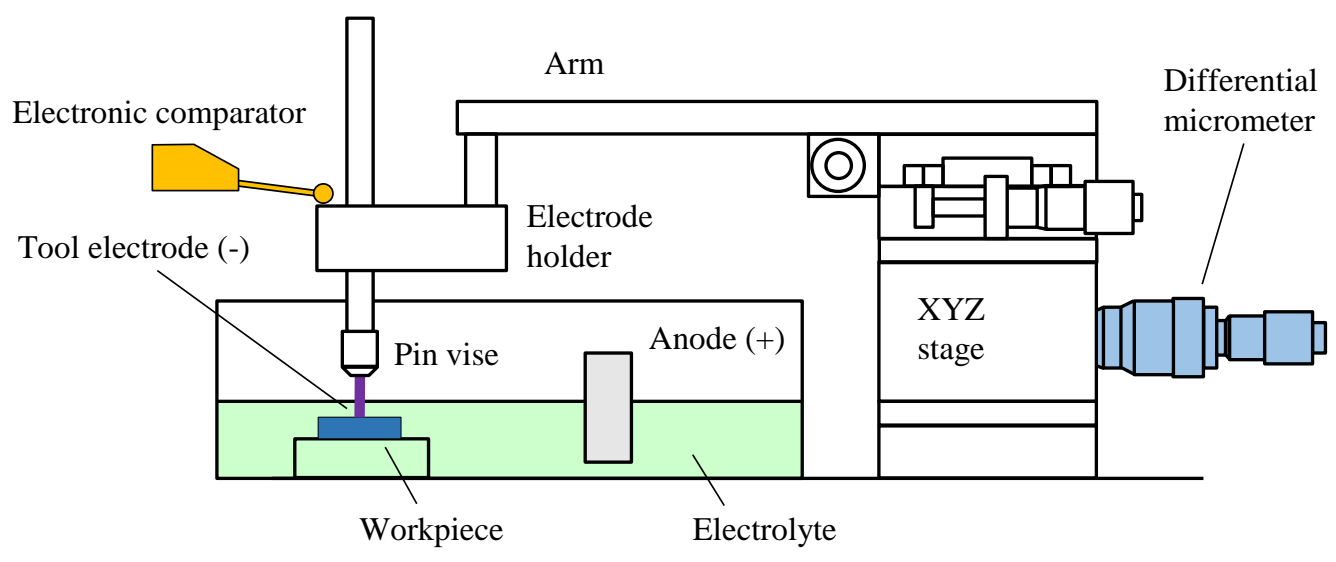

Fig.1 Experimental setup. It consists of an XYZ stage with micrometers, a tool electrode attached at an end of an arm through a pin vise and electric comparator to measure the height of the tool electrode. The tool electrode was shifted with the differential micrometer, and its position was measured with the electronic micrometer. 
Table 1 Machining conditions. The levels for the applied voltage and the initial gap length between the tool electrode and workpiece were 4 and 3 , respectively.

\begin{tabular}{ll}
\hline \hline Applied voltage & $40,45,50,55 \mathrm{~V}$ \\
Initial gap length & $0,25,50 \mu \mathrm{m}$ \\
Tool electrode & Tungsten rod $(0.3 \mathrm{~mm}$ in diameter $)$ \\
Anode & Graphite; $\phi 20 \mathrm{~mm} \times 30 \mathrm{~mm}(100 \mathrm{~mm}$ away from tool electrode $)$ \\
Electrolyte & $\mathrm{NaCl} 20 \mathrm{wt} \%$ solution, depth $4 \mathrm{~mm}$ \\
Workpiece & Soda lime glass, $25 \mathrm{~mm} \times 25 \mathrm{~mm} \times \mathrm{t} 1.2-1.5 \mathrm{~mm}$ \\
Machining time & $60 \mathrm{~s}$ \\
Acquired data & 50000 points with interval of $10 \mu$ s after 30 s elapsed \\
\hline \hline
\end{tabular}

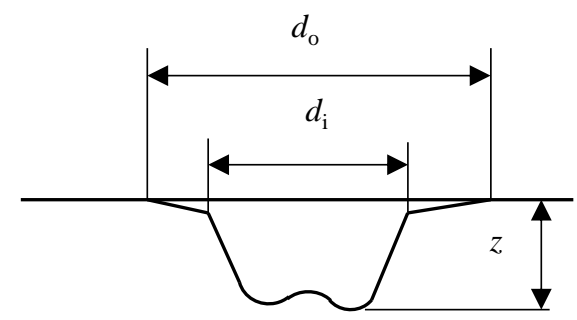

Fig. 2 Definition of dimensions of machined hole. It is illustrated as a cross-sectional view. A machined area $d_{0}$ roughens wider than a hole $d_{\mathrm{i}}$. The depth of the hole $z$ is defined as the deepest point. They were measured with a video microscope.

（2） 1 回あたりの電極ホルダ変位が $50 \mu \mathrm{m}$ より小さくなったら接触しているので，差動マイクロメータの騒動 で $50 \mu \mathrm{m}$ 電極を上げる.

（3） Z 軸ステージの差動マイクロメータの微動で $10 \mu \mathrm{m}$ ずつ電極を下げる.

（4）1 回あたりの電極ホルダ変位が $10 \mu \mathrm{m}$ より小さくなったら, 差動マイクロメータの微動で $10 \mu \mathrm{m}$ 電極を上 げる.

（5）差動マイクロメータの微動で $1 \mu \mathrm{m}$ ずつ下げて，電気マイクロメータで測定した電極ホルダ変位と差動マ イクロメータで読み取ったステージ送りが一致する高さで止める.ここが工作物と工具電極が接している 間隙 $0 \mu \mathrm{m}$ の位置で，かつ，押し付け力がかかっていない状態である.

（6）初期間隙を広げる場合には，電気マイクロメータで変位を測定しながら差動マイクロメータを用いて工具 電極を上昇させる.

加工穴寸法の定義を図 2 に示す. ビデオマイクロスコープ (キーエンス製 VHX-900F, VH-Z50) でレンズ倍 率を 100 倍として上面から観察した．表面が荒れた領域 $d_{\mathrm{o}}$ を加工範囲とし，急に深くなり始める範囲を穴 $d_{\mathrm{i}}$ と定 義した．穴深さ $z$ は，レンズ倍率を 100 倍として $d_{\mathrm{i}}$ の範囲で最も深い位置を探し，レンズ倍率を 500 倍にして鏡 筒を $1 \mu \mathrm{m}$ ずつすらしながら焦点を合わせて測定した高さと, 同様にして求めた $d_{\mathrm{o}}$ の範囲外の高さとの差として 求めた. 断面プロファイルは，レンズ倍率を 100 倍として撮った画像を合成したデータから求めた.

電流波形は，12 ビットディジタルオシロスコープを用いて，加工開始後 $30 \mathrm{~s}$ の時点でサンプリング時間を $10 \mu \mathrm{s}$ として $0.5 \mathrm{~s}$ 間取得した.

\section{3. 実験結果}

\section{$3 \cdot 1$ 加工結果}

目視により泡と放電の量を観察した. 印加電圧が 40，45Vでは泡の量が多かったが，放電はあまり観察されな かった． 50，55Vでは泡の量が減ったが，放電の音が大きく，発光が非常に強かった。したがって，これまでの 著者ら(Furutani et al., 2014)および他グループ(Laio et al., 2013)による研究結果も考慮すると，工具電極周りは図 3 


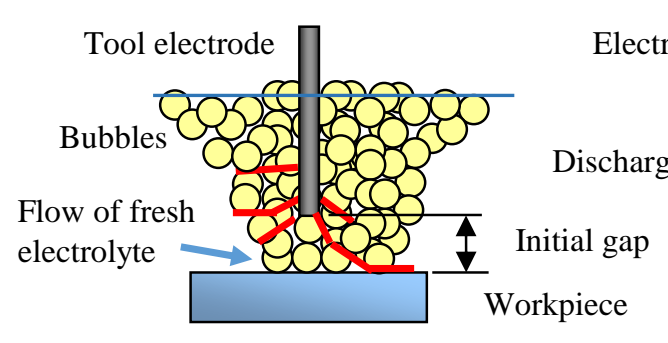

(a) Below $45 \mathrm{~V}$.

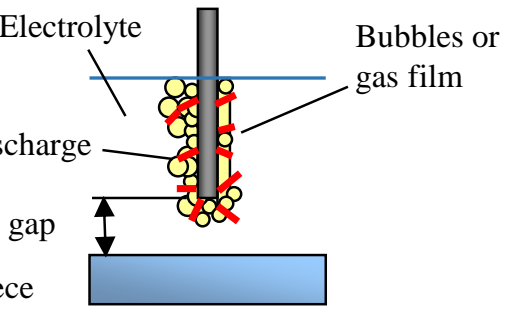

(b) Over $50 \mathrm{~V}$.

Fig. 3 Schematic view of bubbles and discharge around tool electrode with gap. The tool electrode usually contacts on the workpiece with a gentle pressure. However, the effects of the initial gap length were also investigated in this paper. The bubble layer was thick and the discharge density was sparse below $45 \mathrm{~V}$. The discharge simultaneously occurs during generating bubbles. The fresh electrolyte periodically flows toward the tool electrode. The bubble layer was thin and the discharge was dense over $50 \mathrm{~V}$. The thin gas film is sometimes formed by coalescing vaporized electrolyte.

のようになっていると考えられる．45V 以下では電気分解が激しく起こり泡が広い範囲に存在するが，電圧が低 いため放電が発生しにくい. 工作物表面の泡が存在する範囲で放電が起こると加工が進むため, 加工される範囲 も広くなる可能性が高い，それ以上になると，放電が起こりやすくなるとともに泡の発生が少なくなり，泡が存 在寸る範囲が狭くなる．電解液中の泡の膜には $\mathrm{Na}^{+}$が含まれているため，そこで放電が起こることで加工が促進 される(土屋他, 1987). したがって, どちらかが欠けても加工量は減少する. 泡の量が増えると電流が流れにくく なるため, 泡の発生量が減少して加工液が流入寸る．放電が激しくなると，その放電の熱で加工液が気化して泡 や蒸気の層が形成される．放電加工ではアーク放電時に極間電圧が低下寸るため 1 か所でしか放電しない．しか し，3.2 節で示寸ように電解放電加工では極間電圧が一定であるため, 複数箇所で同時に放電が起こったり, 放電 中に別の場所で泡が発生することも起こりうる.

加工した穴の外観例および断面プロファイルを図 4 に示す. 断面は中心付近の X 軸と平行な方向とした. $40 \mathrm{~V}$ の場合には，中心部に除去されない部分が残った。これは，電圧が低く放電しにくいため，電解液までの経路が 長くなる工具電極底面部では放電頻度が低くなることが原因であると考えられる，45V の場合には大量の泡が発 生するとともに放電も発生し, 大きな穴があいた. 放電は $55 \mathrm{~V}$ の場合が最も激しかったが, 加工量は最低となり, 初期間隙が $50 \mu \mathrm{m}$ の場合には加工痕が見つからない場合があった.

加工穴の寸法を図 5 に示寸. 5 個の最大值と最小值をエラーバーで示した。近似曲線は 2 次とした. ばらつき があるものの穴径，加工範囲，深さともに，45V の場合が最大になった．初期間隙が小さいほどすべての寸法が 大きくなった．工具電極位置を固定しているため，初期間隙広いと放電の影響が及ぶ範囲から外れることが原因 であると考えられる. 加工穴直径や加工範囲は $45 \mathrm{~V} や 50 \mathrm{~V}$ では $1 \mathrm{~mm}$ を超えているので，水平方向への広がりは $1 \mathrm{~mm}$ を超える場合があると考えられる. しかし，垂直方向には重力の影響により厚くなりにくく，初期間隙の影 響として表れる．初期間隙が $50 \mu \mathrm{m}$ の場合には，すべての量のばらつきが非常に大きかった．工具電極と工作物 が接触しているか近接していると，加工が進しでもその間隙には泡が存在しやすい. 加工初期に間隙長よりも泡 の厚さが薄いと，加工液の流れや泡の浮力により間隙に泡が存在しにくくなる． $50 \mathrm{~V}$ 以上での加工量が $25 \mu \mathrm{m}$ の 場合に比べて大きく減少しているので，工具電極表面近傍の泡の層の厚さは 50〜 $100 \mu \mathrm{m}$ 程度であると推定され る. これらの傾向は, 図3で示した泡の存在する範囲と一致した.

\section{$3 \cdot 2$ 電流波形}

初期間隙を $0 \mu \mathrm{m}$ とした場合の電流波形および確率密度関数の例を図 6 に示す. $40,45 \mathrm{~V}$ の場合にはピーク值が 3〜 4A 程度となったが, 3.1 節で述べたように放電による発光の頻度は低かった. また, $40 \mathrm{~V}$ の場合には電流のピ 一ク值も周期的に大きく変動した，一方，50，55V の場合には，2A 以下のピーク值であったが，発光の頻度は高 かった．ピーク值の変動は少なかった．工具電極の底面積は浸漬部の側面積に比べて無視できるくらい小さいの で, 初期間隙が $0 \mu \mathrm{m}$ で工具電極底面が工作物に接触している場合でも，間隙があいている場合と電流波形の差は なかった. 電流值の確率密度や累積確率は, $50 \mathrm{~V}$ の場合を除き, $1 \mathrm{~A}$ 以下で大きくなった. 電流がまったく流れて 
40

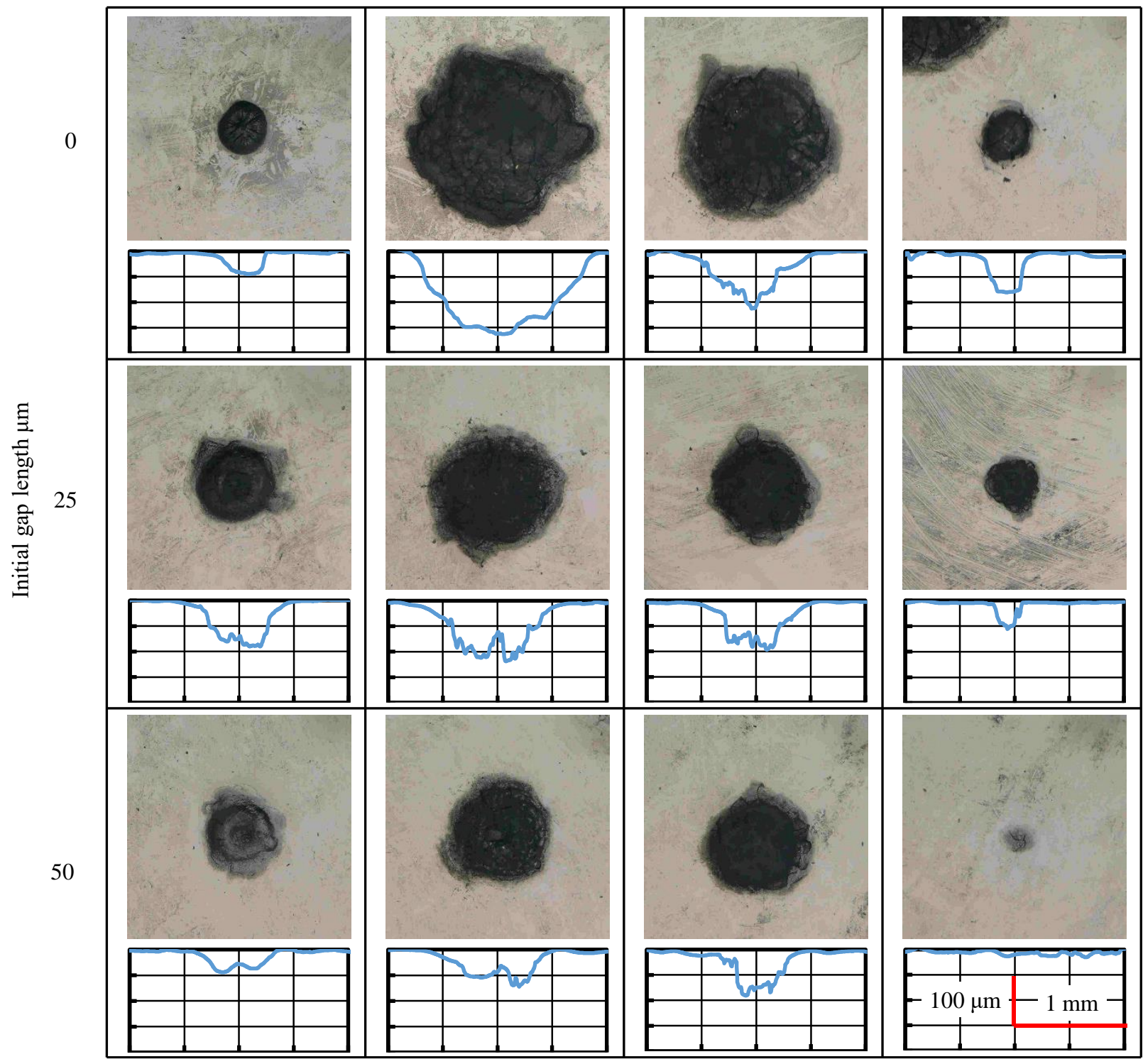

Fig. 4 Examples of machined holes. They are observed with the video microscope from above. Both the applied voltage and initial gap length affected the hole diameter, machined area and depth. The profiles were measured by combining confocal pictures.

いない場合には, 確率密度や累積確率が $0 \mathrm{~A}$ が 1 で最大となる.したがって, これらの場合には $1 \mathrm{~A}$ 以下で両者が 大きく, デューティーが低いことを示している.

電流波形の拡大を図 7 に示寸，同図(a)の 40V，同図(b)の $45 \mathrm{~V}$ ではパルス状の電流が観察され，特に $45 \mathrm{~V}$ では $100 \mu \mathrm{s}$ 以下の電流パルスが頻発していた。一方，同図(c)の $50 \mathrm{~V}$, 同図(d)の $55 \mathrm{~V}$ ではオフセット電流が流れ続ける

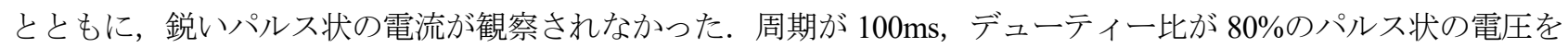
印加した場合には，過渡状態である印加電圧の立ち上がり時に数 $\mathrm{ms}$ 間電流が流れた後, 数十 $\mu \mathrm{s}$ 間電流が複数回 流れた(Furutani et al., 2018). 加工メカニズムからは，前者の長いパルスが電解作用により泡を発生させ，後者の 短いパルスが放電であると推測できる. 今回の実験では連続的に電圧を印加し，定常状態で観察している．40V の場合には放電がほとんど発生せずに泡が発生しただけであるため，40V の場合に多く表れている 100

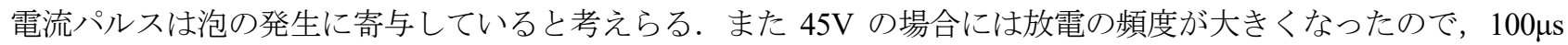
以下の電流パルスは放電であると考えられる。一方， $50 \mathrm{~V}$ およ゙ $55 \mathrm{~V}$ の場合には，工具電極に流れる電流を 1 台 


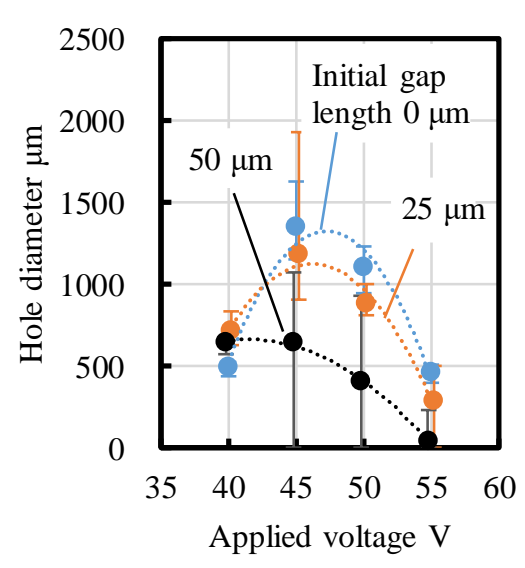

(a) Hole diameter.

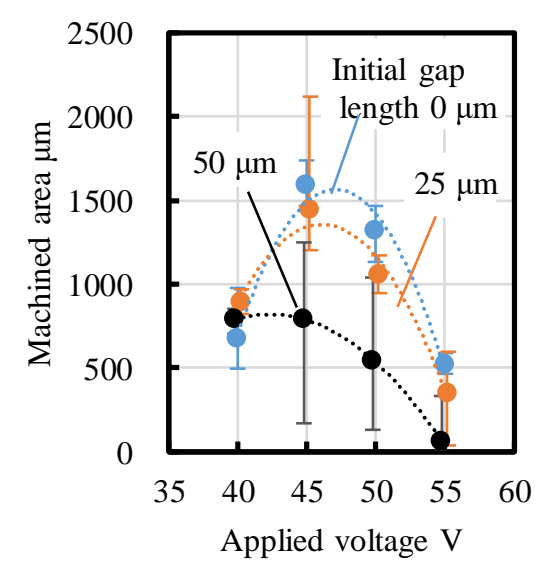

(b) Machined area.

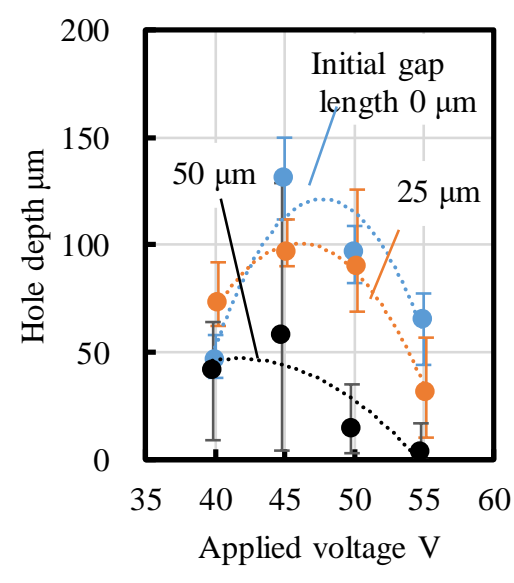

(c) Hole depth.

Fig. 5 Relationship between dimensions of machined holes and applied voltage. All the dimensions were maximum at an initial gap length of $0 \mu \mathrm{m}$ and applied voltage of $45 \mathrm{~V}$, and were dispersed at an initial gap of $50 \mu \mathrm{m}$.

の電流センサでモニタしているため区別ができないが，放電が複数箇所で連続して発生している可能性もある. 放電が発生すると温度が上昇するが，電解液が供給されないとナトリウムイオンがないため化学反応が起こらな くなる．長いパルスと短いパルスが混在する場合には電解液が供給され，かつ，放電も発生しており，加工が促 進されたと考えられる.

電流波形の周波数成分を図 8 に示す。測定值の最初からの 32768 点を使用した。 $40 \mathrm{~V}$ の場合には電流のピーク 值の変動が $100 \mathrm{~Hz}$ 以下の成分として観察された。しかし，45V 以上では放電が安定し，100Hz以下の成分が小さ くなった.また，50，55V では鋭いパルスが発生しなかったため， $1 \mathrm{kHz}$ 以上の成分も減少した.

加工状態の遷移を図 9 に示す。図 3 にも示した通り，40，45V の場合には，電気分解が泡の発生の主な要因で ある．泡の増加と減少を繰り返し，減少した部位で放電が発生していると考えられる．50，55Vの場合には，放 電の熱も大きく寄与していると考えられる. どちらの場合にも, 図に示したサイクルを繰り返すことにより, 電 流が周期的に変動している.

\section{$3 \cdot 3$ 電流波形の主成分分析}

3.2 節で述べたように，定常状態で放電が激しい場合には電解作用と放電が同時に発生していると考えられ， 個々の電流パルスを分離することが困難である.そこで，全体的な傾向として電流波形の特徴を分類するため， 主成分分析を適用した。

図 6 に示した電流波形のデータを 4096 点ごとの 12 区間に分割し，4 通りの印加電圧值のデータをまとめて 48 個のデータを作成し, まとめて解析した. まず, 基本的な統計量として, それぞれの平均, 中央值 (メディアン), 最頻值 (モード), 標準偏差, 尖度, 歪度, 最大值, 最小值を計算した。これらの值を用いて主成分分析した結果 を図 10 に示す，異なる量を用いるため，それぞれの平均值との差を標準偏差で割って標準化した。同図(a)の変 量プロットでは，標準偏差を除いて，第 1 主成分に関する変量の絶対值が大きかった。また，最大值以外の単な る量は正に，分布を表す尖度と歪度は負になった。第 2 主成分はすべて正になったが，それ以外の傾向は見られ なかった．寄与率は第 1 主成分が 0.581 , 第 2 主成分が 0.231 , これらの和が 0.812 であったため, これらだけで ほぼ特徵を表すことができると考えられる.同図(b)の主成分得点プロットでは，40V と $55 \mathrm{~V}$ の結果のばらつきが 大きかった．また，40V と $45 \mathrm{~V}$ は分離できなかった。これらから第 1 主成分は泡の量を表し，小さいほど泡が多 いと考えられる．第 2 主成分は電流の不安定性を表し，大きい方が変動していると考えられる. 同図(b)の得点プ ロットでは，泡の発生や放電の様子が異なる $45 \mathrm{~V}$ 以下と $50 \mathrm{~V}$ 以上でクラスタ化できた.

次に，上記時間波形を周波数解析したデータを 48 個用いて，主成分分析した結果を図 11 に示す. FFTに用い た 1 区間のデータ数が 4096 点であるため, 周波数分解能は約 $25 \mathrm{~Hz}$ となり, 図 8 で示した $100 \mathrm{~Hz}$ 以下の成分の影 響が小さくなっている，同図(a)の変量プロットでは，左上になるほど周波数が高い成分に対応する。直流成分で 

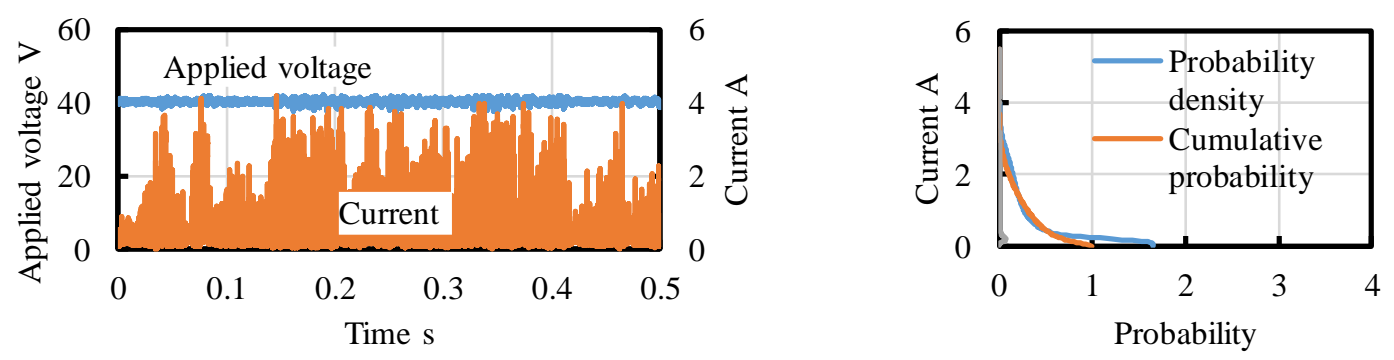

(a) $40 \mathrm{~V}$.
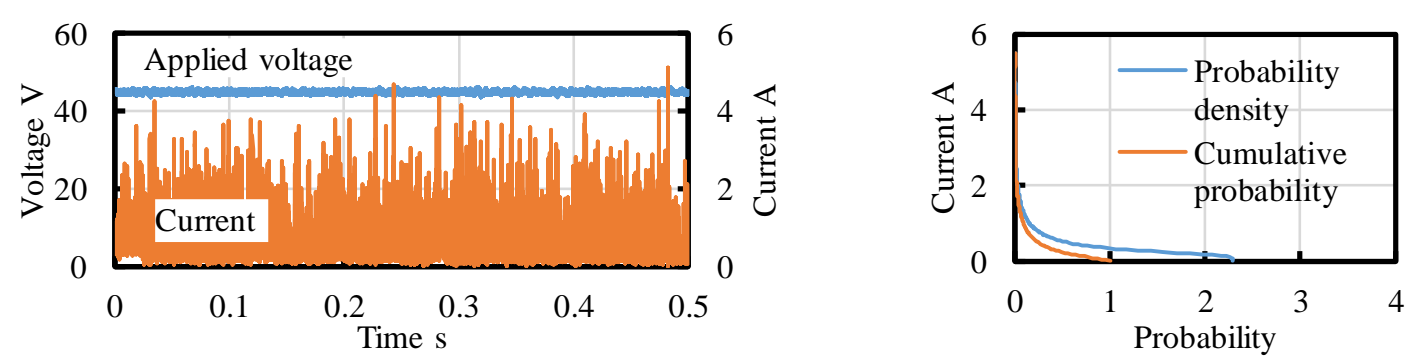

(b) $45 \mathrm{~V}$.
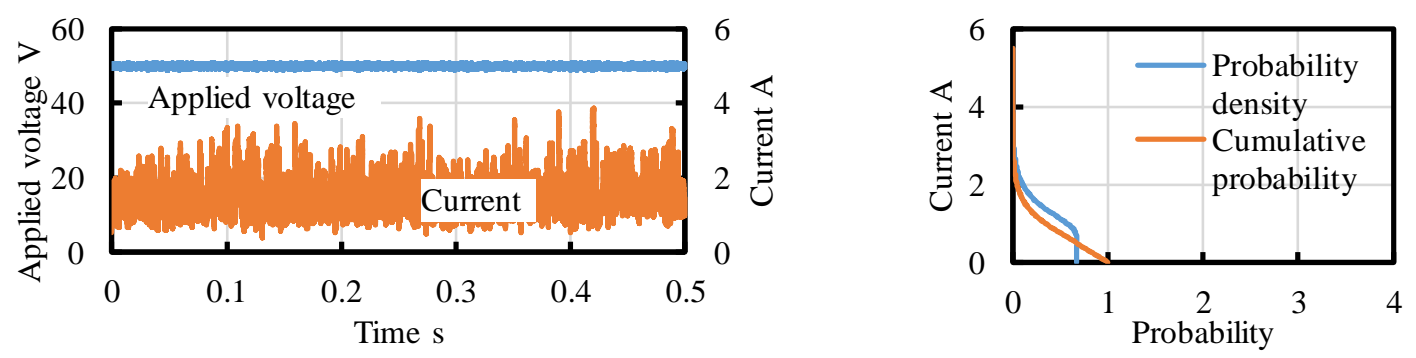

(c) $50 \mathrm{~V}$.
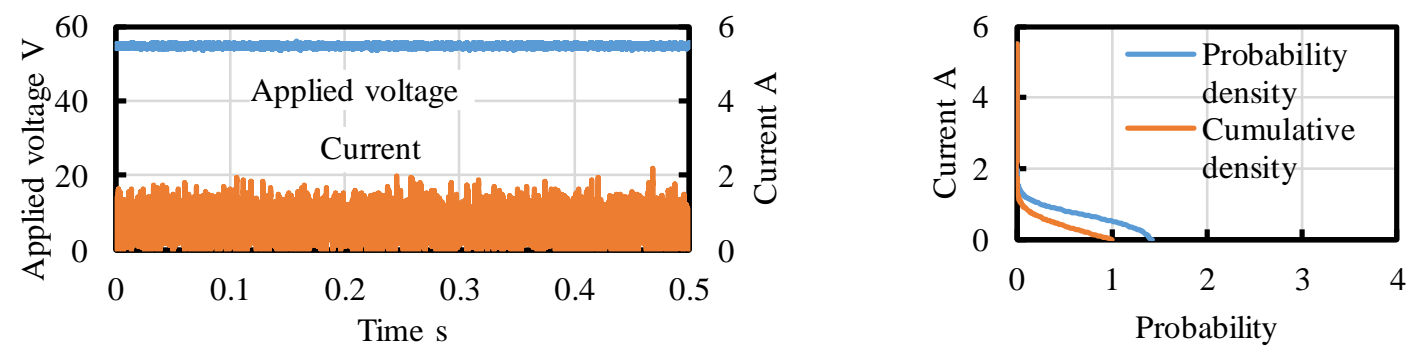

(d) $55 \mathrm{~V}$.

Fig. 6 Examples of current waveforms and their probability density. The probability density below $1 \mathrm{~A}$ was large except $50 \mathrm{~V}$. This means that the duty ratio was low.

ある $0 \mathrm{~Hz}$ の変量は $(0.980,0.110)$ であり，同図の範囲外であるため示していない.この点の絶対值が 1 に近いた め, 他の第 1 次主成分に関寸る変量は非常に小さくなった. それ以外の変量はすべてグラフで示した範囲に入っ た。この場合の寄与率は，第 1 主成分が 0.804 , 第 2 主成分が 0.072 , これらの和が 0.877 であり, 第 1 主成分だ けでも十分に傾向を示していると考えられる．図 8 に示したように，周波数が高いほど成分が小さい傾向がある ため，低い方からの 200 点だけを用いても傾向は変わらなかった，一方，直流成分を除いて主成分分析した場合 の寄与率は，第 1 主成分が 0.373 ，第 2 主成分が 0.101 ，これらの和が 0.475 であるので，直流成分（平均值）が 状態の分類に大きな影響を与えると考えられる. 


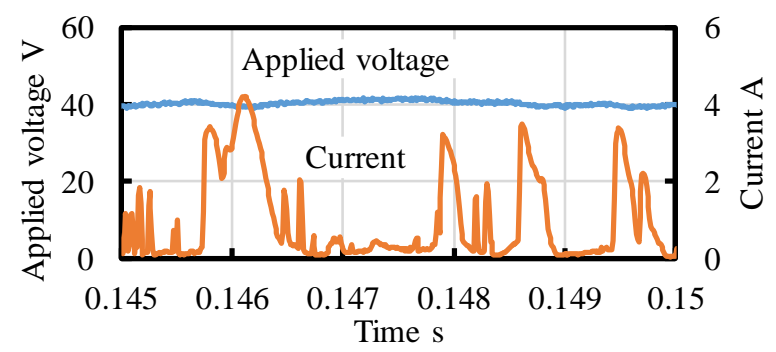

(a) $40 \mathrm{~V}$.

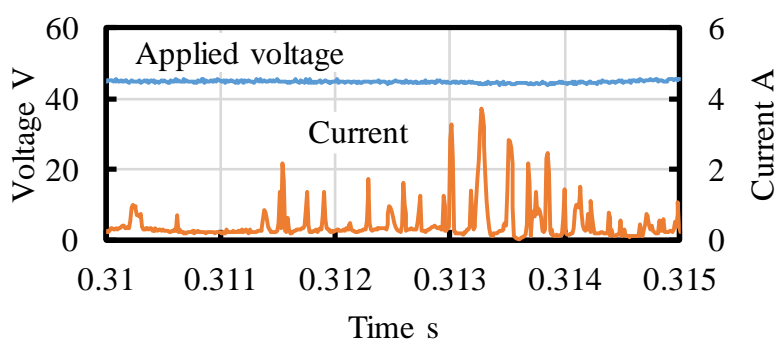

(b) $45 \mathrm{~V}$.

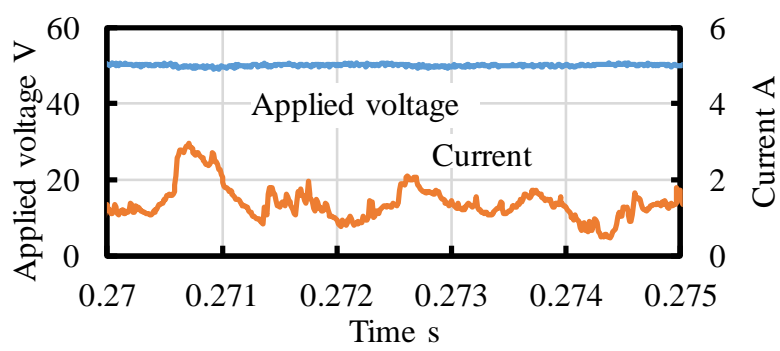

(c) $50 \mathrm{~V}$.

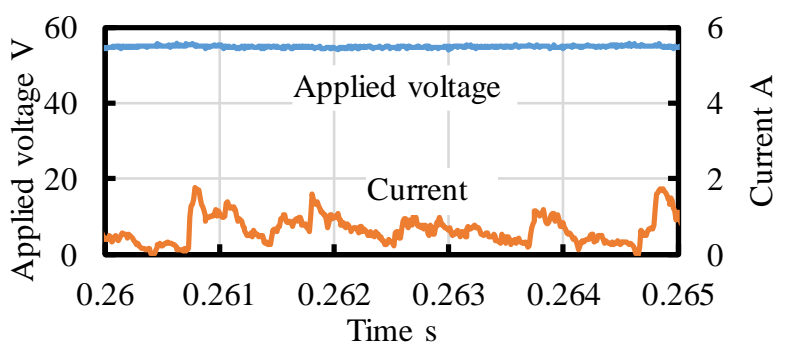

(d) $55 \mathrm{~V}$.

Fig. 7 Expanded view of current waveforms. The pulselike current flew below an applied voltage of $45 \mathrm{~V}$.

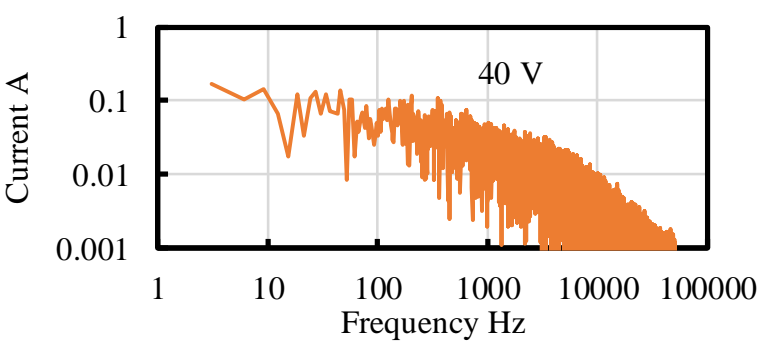

(a) $40 \mathrm{~V}$.

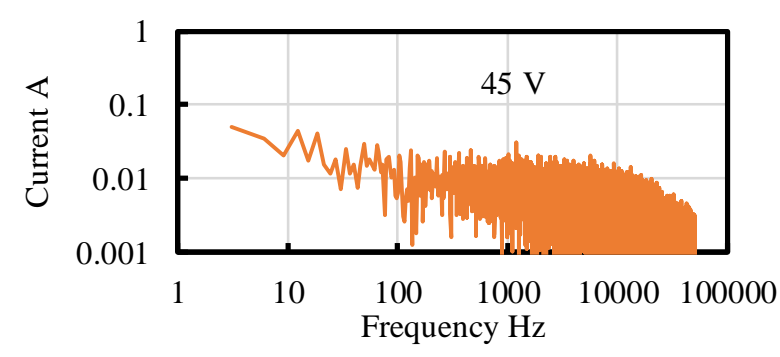

(b) $45 \mathrm{~V}$.

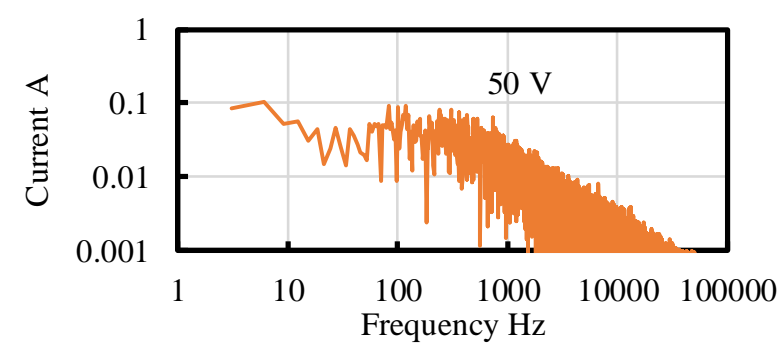

(c) $50 \mathrm{~V}$.

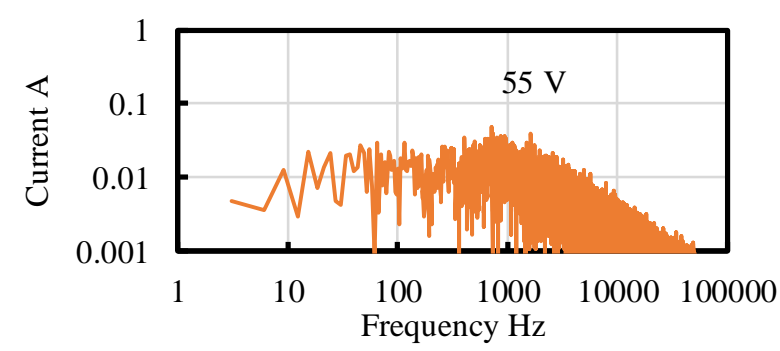

(d) $55 \mathrm{~V}$.

Fig. 8 Frequency components of current waveforms. 32768 points from the beginning were used for the fast Fourier transformation (FFT).

各印加電圧における 12 個のデータ間の相関係数を表 2 に示す. $45 \mathrm{~V}$ 以下での相関係数は， $50 \mathrm{~V}$ 以上でのもの よりわずかに小さかった. 低い電圧では放電の頻度が下がり,波形にむらが出たことが原因であると考えられる.

\section{4. 結言}

本論文では，工具電極と工作物との間隙および印加電圧が電流波形および加工特性に与える影響を実験的に調 べるとともに，電流波形を解析した．結果をまとめると以下となる.

（1） $10 \mu \mathrm{s}$ オーダの電流パルスが頻発する $45 \mathrm{~V}$ の場合に加工量が大きかった. 電流值の確率密度や累積確率は, $50 \mathrm{~V}$ の場合を除き, デューティーが低いため $1 \mathrm{~A}$ 以下で大きくなった. 


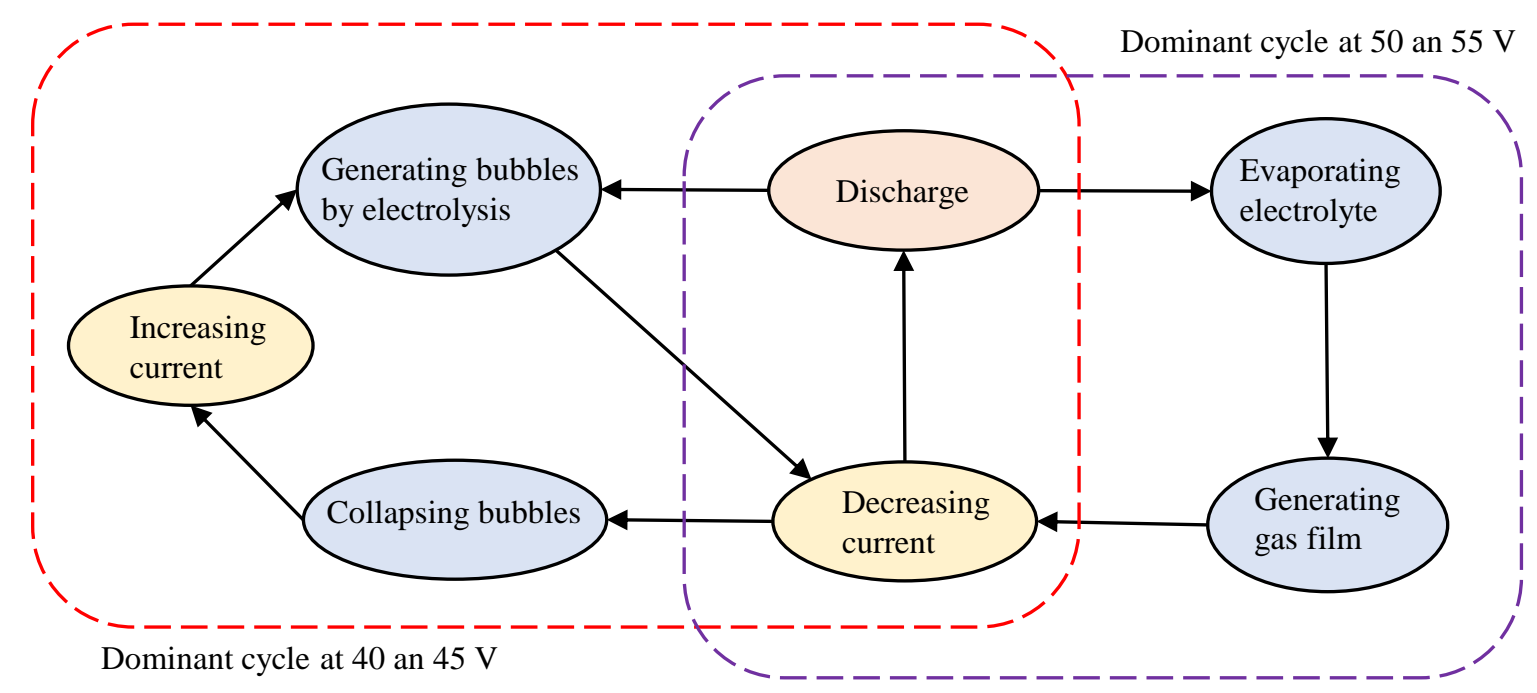

Fig. 9 State transition diagram of electrochemical discharge machining. The bubbles are generated mainly by electrolysis at 40 and $45 \mathrm{~V}$ as shown in the red box. They are generated also by discharge heat at 50 and $55 \mathrm{~V}$ as shown in the violet box. The several discharges may occur simultaneously while bubbles and gas film are generated.

（2）工具電極の底面積は浸漬部の側面積に比べて無視できるくらい小さいので，初期間隙は電流波形に影響を 及ぼさなかった。しかし，間隙が大きくなるほど加工量は減少し，電圧が高く加工量が小さい場合には加 工痕が観察されないことがあった。

（3）電流波形の基本的な統計量と周波数成分用いて主成分分析した結果，基本的な統計量で泡の発生や放電 の状態を分類できることが明らかになった．周波数成分では，直流成分の影響が大きいことが明らかにな った．しかし，各主成分が表寸傾向は明確でない場合もあった。

泡の発生量が加工される領域に影響を与えていると考えられるため，今後は，放電の発生状態と泡の発生量の 関係についての定量的な評価が必要であると考えられる.

\section{謝辞 \\ 本研究の一部にはJSPS 科学研究費補助金基盤研究 (C)（JP18K03885）を用いました. 記して感謝いたします.}

\section{文献}

Abidi, M. H., Al-Ahmari, A. M., Siddiquee, A. N., Mian, S. H., Mohammed, M. K. and Rasheed, M. S., An investigation of the micro-electrical discharge machining of nickel-titanium shape memory alloy using grey relations coupled with principal component analysis, Metals, Vol. 7, No. 11 (2017), 486.

Ancio, F., Gamez, A. J. and Marcos, M., Study of turned surfaces by principal component analysis, Precision Engineering, Vol. 43, No. 1 (2016), pp. 418-428.

Arab, J., Adhare, P., Mishra, D. K. and Dixit, P., Micro array hole formation in glass using electrochemical discharge machining, Procedia Manufacturing, Vol. 34 (2019), pp. 349-354.

Arya, R. K. and Dvivedi, A., Investigations on quantification and replenishment of vaporized electrolyte during deep microholes drilling using pressurized flow-ECDM process, Journal of Materials Processing Technology, Vol. 266 (2019), pp. 217-229.

Basak, I. and Ghosh, A., Mechanism of spark generation during electrochemical discharge machining: A theoretical model and experimental verification, Journal of Material Processing Technology, Vol. 62, No. 1-3 (1996), pp. 46-53.

Cao, X. D., Chu, C. N. and Kim, B. H., Micro-structuring of glass with features less than $100 \mu \mathrm{m}$ by electrochemical discharge machining, Precision Engineering, Vol. 33, No. 4 (2009), pp. 459-465.

Elhami, S. and Razfar, M. R., Numerical and experimental study of discharge mechanism in the electrochemical discharge machining process, Journal of Manufacturing Processes, Vol. 50 (2020), pp. 192-203. 


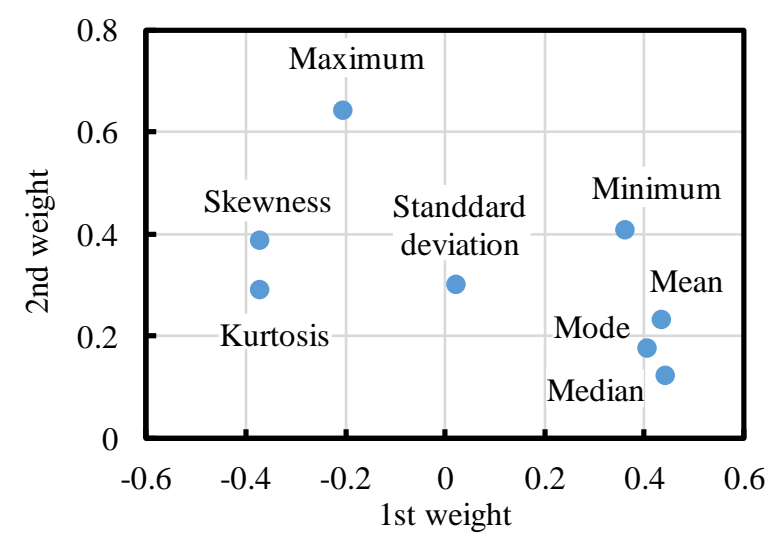

(a) Weight.

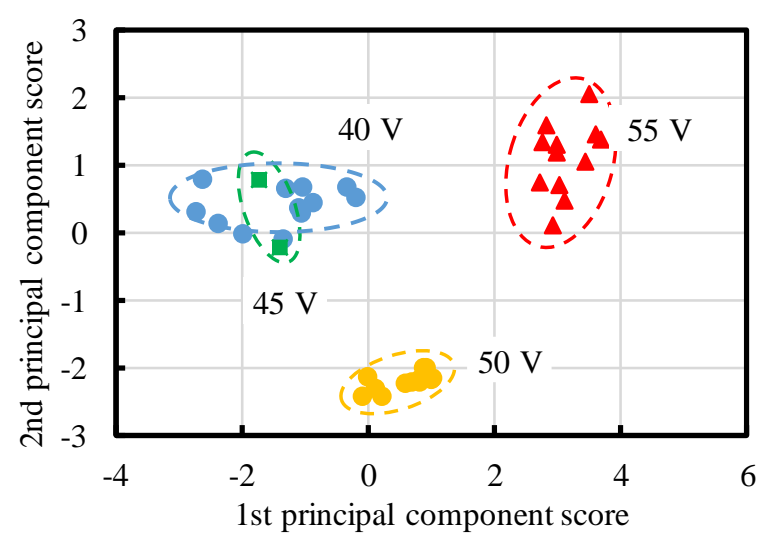

(b) Score.

Fig. 10 Result of principal component analysis of statistics values. The average, median, mode, standard deviation, kurtosis, skewness, maximum and minimum were used. The proportions were 0.581 , 0.231 and 0.812 for the first, second principal components and their sum, respectively. The first and second principal components indicate the bubble amount and instability of peak current, respectively. The data are divided into two clusters.

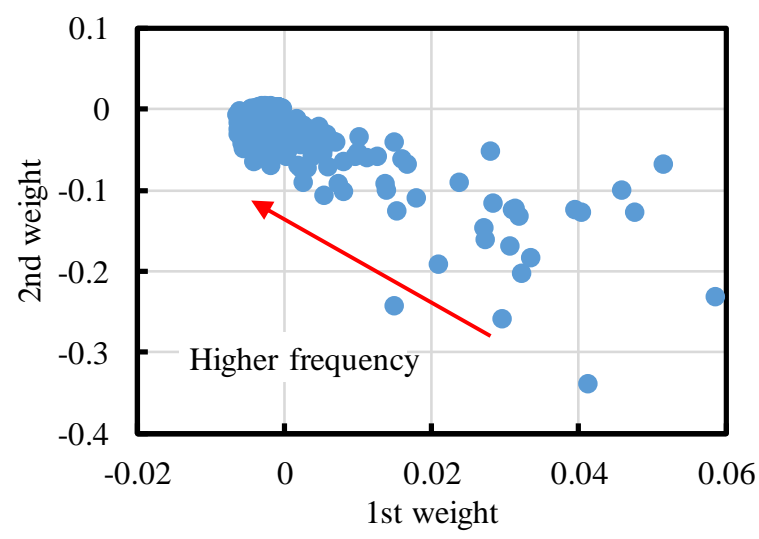

(a) Weight.

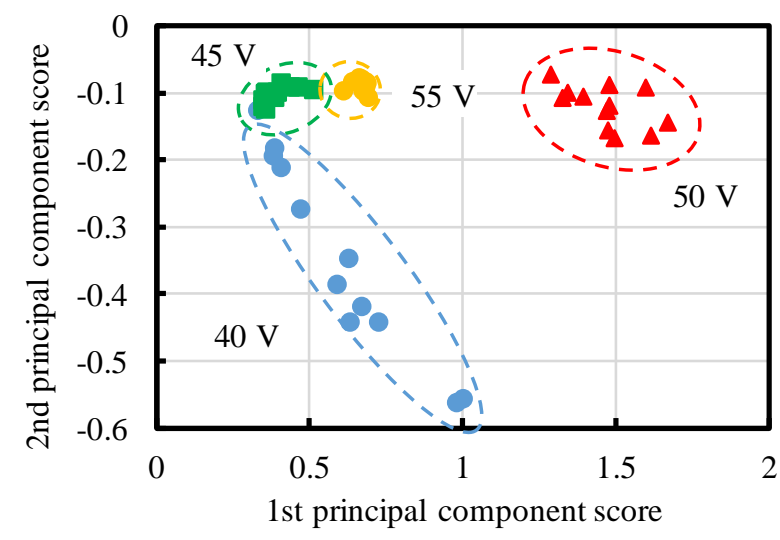

(b) Score.

Fig. 11 Result of principal component analysis of frequency components. The weights at $0 \mathrm{~Hz}$ were $(0.980,0.110)$, which is not shown. The proportions were 0.58040 .072 and 0.877 for the first, second components and their sum, respectively. The weights in the upper left area indicate higher frequency. Dividing data into clusters based on the discharge conditions is knotty.

Table 2 Correlation among frequency components in 12 periods in each current waveforms. The effects of lower frequency components were dominantly because they were larger than higher ones.

\begin{tabular}{lcccc}
\hline \hline Applied voltage V & 40 & 45 & 50 & 55 \\
\hline Average & 0.898 & 0.916 & 0.988 & 0.976 \\
Standard deviation & 0.002 & 0.001 & 0.000 & 0.000 \\
Maximum & 0.936 & 0.940 & 0.993 & 0.983 \\
Minimum & 0.832 & 0.888 & 0.983 & 0.968 \\
\hline \hline
\end{tabular}

Furutani, K. and Kojima, S., Prototyping of acceleration sensor by using lathe-type Electro-chemical Discharge Machine, Procedia CIRP, Vol. 42 (2016), pp. 772-777.

Furutani, K. and Maeda, H., Machining a glass rod with a lathe-type electro-chemical discharge machine, Journal of Miceomechanics and Microengineering, Vol. 18, No. 6 (2008), 065006.

Furutani, K., Shintani, H., Murase, Y. and Arakawa, S., Performance of electrochemical discharge machining by forced 
discharge dispersion, International Journal of Electrical Machining, No. 19 (2014), pp. 9-15.

Furutani, K., Shintani, H., Murase, Y. and Arakawa, S., Performance of electrochemical discharge machining by forced discharge dispersion (2nd report) monitoring of machining current, International Journal of Electrical Machining, No. 23 (2018), pp. 16-23.

Huang, G., Xia, W., Qin, L. and Zhao, W., Online Workpiece height estimation for reciprocated traveling wire EDM based on support vector machine, Procedia CIRP, Vol. 68 (2018), pp. 126-131.

Kasdekar, D. K. and Parashar, V., Principal component analysis to optimize the ECM parameters of aluminium alloy, Materials Today: Proceedings, Vol. 5, No. 2 (2018), pp. 5398-5406.

Kim, D. J., Ahn, Y., Lee, S. H. and Kim, Y. K., Voltage pulse frequency and duty ratio effects in an electrochemical discharge microdrilling process of Pyrex glass, International Journal of Machine Tools and Manufacture, Vol. 46, No. 10 (2006), pp. 1064-1067.

Laio, Y. S., Wu, L. C. and Peng, W. Y., A study to improve drilling quality of electrochemical discharge machining (ECDM) process, Procedia CIRP, Vol. 6 (2013), pp. 609-614.

土屋八郎, 後藤英和, 宮崎真, 井上友一：ワイヤ電解放電加工に関する研究（第 1 報）一ガラスおよびセラミッ クス材料の加工特性一, 電気加工学会誌, Vol. 20, No. 40 (1987), pp. 24-31.

辻野元太，古城直道，廣岡大祐，山口智実，松田茂敬，岩佐康弘，寺内俊太郎，浸炭した鋼のダイヤモンド切削 においてミクロ組織が工具摩耗に及ぼす影響, 2017 年度精密工学会春季大会学術講演会講演論文集 (2017), pp. 645-646.

\section{References}

Abidi, M. H., Al-Ahmari, A. M., Siddiquee, A. N., Mian, S. H., Mohammed, M. K. and Rasheed, M. S., An investigation of the micro-electrical discharge machining of nickel-titanium shape memory alloy using grey relations coupled with principal component analysis, Metals, Vol. 7, No. 11 (2017), 486.

Ancio, F., Gamez, A. J. and Marcos, M., Study of turned surfaces by principal component analysis, Precision Engineering, Vol. 43, No. 1 (2016), pp. 418-428.

Arab, J., Adhare, P., Mishra, D. K. and Dixit, P., Micro array hole formation in glass using electrochemical discharge machining, Procedia Manufacturing, Vol. 34 (2019), pp. 349-354.

Arya, R. K. and Dvivedi, A., Investigations on quantification and replenishment of vaporized electrolyte during deep microholes drilling using pressurized flow-ECDM process, Journal of Materials Processing Technology, Vol. 266 (2019), pp. 217-229.

Basak, I. and Ghosh, A., Mechanism of spark generation during electrochemical discharge machining: A theoretical model and experimental verification, Journal of Material Processing Technology, Vol. 62, No. 1-3 (1996), pp. 46-53.

Cao, X. D., Chu, C. N. and Kim, B. H., Micro-structuring of glass with features less than $100 \mu \mathrm{m}$ by electrochemical discharge machining, Precision Engineering, Vol. 33, No. 4 (2009), pp. 459-465.

Elhami, S. and Razfar, M. R., Numerical and experimental study of discharge mechanism in the electrochemical discharge machining process, Journal of Manufacturing Processes, Vol. 50 (2020), pp. 192-203.

Furutani, K. and Kojima, S., Prototyping of acceleration sensor by using lathe-type electro-chemical discharge machine, Procedia CIRP, Vol. 42 (2016), pp. 772-777.

Furutani, K. and Maeda, H., Machining a glass rod with a lathe-type electro-chemical discharge machine, Journal of Miceomechanics and Microengineering, Vol. 18, No. 6 (2008), 065006.

Furutani, K., Shintani, H., Murase, Y. and Arakawa, S., Performance of electrochemical discharge machining by forced discharge dispersion, International Journal of Electrical Machining, No. 19 (2014), pp. 9-15.

Furutani, K., Shintani, H., Murase, Y. and Arakawa, S., Performance of electrochemical discharge machining by forced discharge dispersion (2nd report) monitoring of machining current, International Journal of Electrical Machining, No. 23 (2018), pp. 16-23.

Huang, G., Xia, W., Qin, L. and Zhao, W., Online workpiece height estimation for reciprocated traveling wire EDM based on support vector machine, Procedia CIRP, Vol. 68 (2018), pp. 126-131.

Kasdekar, D. K. and Parashar, V., Principal component analysis to optimize the ECM parameters of aluminium alloy, Materials Today: Proceedings, Vol. 5, No. 2 (2018), pp. 5398-5406.

Kim, D. J., Ahn, Y., Lee, S. H. and Kim, Y. K., Voltage pulse frequency and duty ratio effects in an electrochemical discharge 
microdrilling process of Pyrex glass, International Journal of Machine Tools and Manufacture, Vol. 46, No. 10 (2006), pp. 1064-1067.

Laio, Y. S., Wu, L. C. and Peng, W. Y., A study to improve drilling quality of electrochemical discharge machining (ECDM) process, Procedia CIRP, Vol. 6 (2013), pp. 609-614.

Tsuchiya, H., Goto, H., Miyazaki, M. and Inoue, T., A study on wire electro-chemical discharge machining (1st report) machining characteristics of glass and ceramics -, Journal of Japan Society for Electrical Machining Engineers, Vol. 20, No. 40 (1987), pp. 24-31 (in Japanese).

Tsujino, G., Furushiro, N., Hirooka, D., Yamaguchi, T., Matsuda, S., Iwasa, Y. and Terauchi, S., Effect of microstructure in suppression of tool wear in diamond turning of carburized steel, Preprint of 2017 Spring Meeting of Japan Society of Precision Engineering (2017), pp. 645-646 (in Japanese). 